\title{
The Determinants of Dividend Policy on Real Estate, Property, and Building Construction Companies Listed in IDX using Unbalanced Panel Data Approach
}

\author{
Powell Gian Hartono a 1 iD, Anita Roosmalina Matusin b iD \\ ${ }^{a}$ Laboratory of Quantitative Analysis Instruments, Faculty of Economics and Business, Trisakti University, Indonesia \\ ${ }^{b}$ Department of Management, Faculty of Economics and Business, Trisakti University, Indonesia
}

\section{APA Citation:}

Hartono, P.G., \& Matusin, A.R. (2020). The determinants of dividend policy on real estate, property, and building construction companies listed in IDX using unbalanced panel data approach. TIJAB (The International Journal of Applied Business), 4(2), 139-156.

Submission Date: $02 / 10 / 2020$

Acceptance Date: $13 / 11 / 2020$

\begin{abstract}
This study involved companies engaging in real estate, property, and building construction companies listed in IDX for 2013 - 2019 period as the population. This research examines 10 factors presumed affect to dividend policy. A total of 21 companies distributed dividends at least once during the research period, and then 96 samples were selected, while 9 samples were discarded as outliers so that 87 samples were selected. Unbalanced panel data regression was employed using the SPSS version 22 and E-Views version 10 to analyze the data and to test the hypotheses. The results showed that the previous year's dividend had a positive effect on dividend policy, while company size had a negative effect on dividend policy. This study proved that previous year's dividend and company size were key variables that determined companies' dividend policy and they were major investment considerations for investors in order to obtain optimal returns. This study also tries to test the conditions of the inconsistency of dividend distribution.
\end{abstract}

Keywords: dividend policy, Indonesia stock exchange, real estate, property, building construction, unbalanced panel data

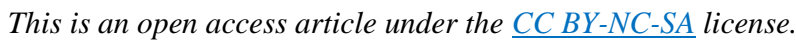

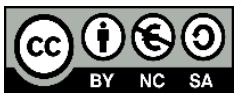

\section{Introduction}

Besides aiming at obtaining greater profits, companies run their business activities to guarantee shareholders' welfare at the maximum level (Sari \& Matusin, 2019). To reach these goals, companies are required to increase the company value to the highest level by carrying out optimal financial managerial function. This function includes investment, funding and dividends policies (Hart \& Zingales, 2017). Companies need to create proper dividend policy to ensure the sustainability of their business activities. Proper dividend policy also provides an opportunity for investors to obtain optimal investment returns (Wilburn \& Wilburn, 2014).

\footnotetext{
${ }^{1}$ Corresponding author.

E-mail address: powel1022167008@std.trisakti.ac.id
} 
Dividend policy determines the proportion of shared profit to shareholders and the total shares retained to increase the proportion of further investment (Sari, 2017). Dividend policy is defined as the distribution of company profits to shareholders which is determined through a general meeting attended by shareholders for certain period (Agyei \& Marfo-Yiadom, 2011). In determining the proportion of dividends and retained earnings, several aspects should be taken into account based on company's goals since the amount of dividends set by a company affects investors' interest to make investment in the company (Leary \& Michaely, 2011).

Yusof and Ismail (2016) conducted a study of 147 public listed companies in Malaysia. Several factors are presumed to influence dividend policy, namely earnings, cash flows, free cash flows, debt level, growth, investment, size, largest shareholders, risk, and lagged dividend. The analysis tools used fixed and random effects, pooled least squares model, robust standard errors on fixed-effects, and random-effects models. The results obtained are earnings, investment, and size have a positive effect on dividend policy, while debt level and largest shareholders have a negative effect on dividend policy.

Sari (2017) identified the factors suspected of influencing state-owned companies' dividend policy listed on the IDX. The research period in the years 2004 - 2013 with as many as 8 companies with multiple linear regression. The selection of state-owned companies is because state-owned companies have dominant and consistent dividend distribution characteristics. Factors that are presumed to affect dividend policy are government ownership, firm size, growth opportunity, financial leverage, profitability, business risk, company age, previous year's dividend, and global crisis in 2008. The results obtained are firm size, previous year's dividend, and the global crisis in 2008 have a positive effect on dividend policy.

Research conducted by Singla \& Samanta (2018) examined the factors presumed to influence construction companies' dividend policy in India. The presumed factors are profitability, unstable earnings, institutional holding, cash flow, tangibility, liquidity, growth opportunities, the firm's age, life cycle, leverage, size of the firm, and taxation. The analytical tools used are the fixed effect model and the random effect model with robust estimation options. Profitability, life cycle, and size of the firm have a positive effect on dividend policy, while cash flow shows a significant negative relationship, indicating the presence of agency problems.

Sharma \& Bakshi (2019) identified the determinants of corporate dividend policy, involving 125 real estate and property companies in India as samples for 2009 - 2017 period with the co-integration regression. This research identified some determinants of dividend policy namely the previous year's dividend, agency cost, firm risk, profitability, company size, financial leverage, liquidity, company growth, growth opportunity, and company age. The results of this study indicated that previous year's dividend, firm risk, company size, and liquidity positively affected the dividend policy.

Research conducted by Wahjudi (2020) examines the influence of predictors presumed to influence dividend policy in manufacturing companies listed on IDX, with the research period of $2011-2015$. The predictors that are presumed to affect dividend policy are collateralizable assets, growth in net assets, liquidity, leverage, and profitability. The results obtained are that growth in net assets, liquidity, and financial leverage has a negative effect on dividend policy.

This research identifies predictors that are presumed to have influenced companies' dividend policy in the real estate, property, and building construction industry listed on the Indonesia Stock Exchange (IDX) in 2013 - 2019. Predictors that are presumed to affect are the previous year's dividend, agency cost, firm risk, profitability, company size, financial leverage, liquidity, company growth, growth opportunity, and company age. A total of 91 companies in this industry, 21 companies distributed dividends at least once during the study period, which means that dividend distribution is inconsistent. Due to the inconsistency of dividend distribution, this study uses an unbalanced panel data approach by 
discarding samples of those who do not distribute dividends in specific periods and companies while maintaining the sample that distributes dividends.

The real estate, property, and building construction industry are interesting sector to be studied for their unique characteristics. As stated by the Minister of Finance of the Republic of Indonesia, the real estate, property, and building construction industry sector contributes significantly to national economic growth since this sector is directly linked to other industrial sectors including material industry, logistics, services, and even the financial and banking industry through housing loans. Real estate, property, and building construction sector provides multiplier effects on employment opportunity (Kencana, 2019).

\section{Literature Review}

Dividend policy plays an important role in projecting companies' business outlook and it strongly affects the stock prices. Dividend policy also supports a company to reach its goals by maximizing shareholders' welfare. Companies that regularly pay the dividends with high proportion will have their stock prices in the market increased, which eventually attracts investors to make investment (Tahir \& Mushtaq, 2016). Likewise, companies that set a relatively stable dividend distribution policy will be more attractive to investors. Investors' trust in the company is influenced by the stability of the dividend rate, thereby avoiding investment uncertainties (Ramli \& Arfan, 2011).

Previous year's dividend is the dividend rate distributed in the period prior to the specified year that is affected by the dividend rate distributed in the previous period. Previous year's dividend is the benchmark in determining the rate of dividends distributed in the current year. Therefore, unfair dividend rate includes gaps in values or significant decreases from the previous period in signaling theory perspective. Well-planned dividend rate determination should be based on optimal targets (Sari, 2017). In this context, previous year's dividend positively affects dividend rate in the current year (Sharma \& Bakshi, 2019).

Agency costs are costs incurred by the company, in this case the shareholders, in controlling and supervising the agents that carry out company management (Jensen \& Meckling, 1976). Control and supervision are carried out by the agents to maximize shareholders' welfare. Agency cost arises due to problems that occur between shareholders as the principle and the company management as the agent that emerges agency cost (Rita \& Sarquella, 2010). Difficult problems require rapid cash flow to finance the costs. In this study, agency cost was measured based on free cash flow which allows cash to be distributed to shareholders and creditors after substituted by total investment on fixed assets, new products, and working capital to fund ongoing operational activities. Agency cost negatively affects dividend policy on free cash flow where agency cost is incurred (Arfan \& Maywindlan, 2013; Sharma \& Bakshi, 2019; Singla \& Samanta, 2018).

According to Patra et al. (2012), company risk or firm risk refers to uncertainties related to expected return on an investment of a company. Company risk in relation to dividend rate is interpreted as risk occurring from changes in the stock price within the context of fulfilling company's capital in generating optimal profits. In this study, the term risk refers to the fluctuation in stock price, which is then interpreted as a measure of company performance in obtaining net income and in determining dividend policy. If the stock price increases due to higher demand for shares, the opportunity for capital will be higher, making it possible to obtain higher profit. The higher the company's profit, the higher the dividend rate and vice versa (Kaźmierska-Jóźwiak, 2015). In perspective of dividend signaling theory, increasing dividend rate is a signal of profit for investors. On the other hand, lower dividend rate is considered a bad signal as it reflects less favorable company outlook which can result in losses. Risk, which is interpreted as the uncertainty of returns in investment activities implicitly shows that the price 
to earnings ratio describes the projected risk of investment in the future, and it is a parameter of company risk variable. (Delikartika \& Ferry, 2017; Sharma \& Bakshi, 2019).

Sharma \& Bakshi (2019) describes company profitability as the ability of a company to generate profits, from which net profit is determined to set the dividend rate. Profitability has a positive effect on dividend policy (Alzomaia \& Al-Khadhiri, 2013). Companies with high profitability are able to set higher dividend rate. Higher dividend rate is also affected by the increase in demand for shares which allows companies to develop their business to enhance their profitability. There is a positive influence of profitability on dividend policy (Jensen \& Meckling, 1976; Sharma \& Bakshi, 2019).

Patra et al. (2012) stated that company size describes company size based on company's total assets. According to Sharma \& Bakshi (2019), company size is measured by several parameters that can be compared to other companies, such as total assets, total sales revenue, and other parameters that are measurable and comparable ratio scale. If the size of the company increases, the company's ability to earn profits will increase, which then increases the dividend rate distributed to shareholders, vice versa. In certain conditions when the size of a company is increasing and more profitable, the company can decide to reduce the dividend rate to increase the proportion of retained earnings for other investment ((Black, 1976; Pribadi \& Sampurno, 2012; Sharma \& Bakshi, 2019; Yusof \& Ismail, 2016). Sharma \& Bakshi (2019) explained that company size is measured from the revenue. High revenue reflects company's ability to run its business (Yusof \& Ismail, 2016).

Financial leverage is defined as the proportion of liabilities and equity on the assets of a company (Sari, 2017). Meanwhile, according to Zutter \& Smart (2019), financial leverage describes company's capital structure on its liabilities and equity to its assets. Greater level of liabilities will increase the cost of the liabilities, while it reduces the amout of net income and decreases the stipulated dividend rate, vice versa (Rehman, 2012; Zutter \& Smart, 2019). Companies play their executive functions in determining their capital structure. The capital structure that consists of debt to equity ratio (DER), negatively affects the dividend rate for shareholders (Alzomaia \& Al-Khadhiri, 2013).

Liquidity is defined as company's ability to pay its short-term liabilities (Zutter \& Smart, 2019). According to Sharma \& Bakshi (2019), liquidity refers to how liquid the current assets to pay short-term due liabilities. Companies with high liquidity are capable of paying dividends to shareholders. Liquidity affects the success or failure of a company. Companies that have an optimal level of liquidity can assure investors that their pefromance is optimal (Kaźmierska-Jóźwiak, 2015). Extremely high liquidity up to certain point shows the unability of a company in optimizing its assets to generate maximum profit. Thus, such condition leads to lower profit earned and lower dividend rate and vice versa as long as the liquidity does not reach the extreme point which can cause inability to pay for current liabilities (Kaźmierska-Jóźwiak, 2015).

Company growth is defined as the development a company makes over time, which is measured by the change in year on year total assets (Sharma \& Bakshi, 2019). Asif et al. (2011), company growth is compared to the growth made in previous year Whilst, company size can be measured by total assets, total revenue on sales, and other parameters (Zutter \& Smart, 2019). Higher company growth is followed by lower dividend rate distributed since the company is considered prospective, while the company increases the proportion of retained earnings for future investments for greater return (Sharma \& Bakshi, 2019). Companies with strong growth tend to retain their revenue for investment. Moreover, in a high growth stage, companies tend to hold back their earnings due to higher demand for additional funds from inside and outside the company. To obtain enough fund, managers rather use internal sources which in this case is retained earnings, for it incurs the lowest cost of equity compared to the costs of debt and issuance of new shares. Such condition causes the dividend rate smaller. Thus, company growth rate has a negative influence on company's dividend policy (Masdupi, 2012). 
Growth opportunity or investment opportunity refers to investment opportunities in the future (Sari, 2017). Growth opportunity is also interpreted as a future investment opportunity influenced by stock market price, which then affects profitability and dividend rate (Singla \& Samanta, 2018). If the higher the market share price, the company value will increase. High company value does not only indicate that the company is performing well, but also indicates that the company is prospective. Companies that have high investment opportunities are prospective require high funds for future investment. Therefore, increasing the proportion of retained earnings is the right choice. In this condition, the company will obtain capital from debts with a proper ratio. Within the perspective of the pecking order theory, companies prefer internal financing over external financing. Thus, using retained earnings is the most appropriate choice. Increasing the proportion of retained earnings will result in a decrease in the proportion of dividends for shareholders. In this context, market price to book value ratio as a proxy of growth opportunity positively affects dividend rate (Sharma \& Bakshi, 2019).

Company age is defined as the period between the time a company is established to the present (Sari, 2017). Company age is also interpreted as the period during which a company runs its business as a legal business entity up to the specified research period (Sharma \& Bakshi, 2019). A company can obtain higher profits based on its age. Greater age increases company's opportunity to set higher dividend rate. Mature companies are considered capable of generating greater profits, which in turn will increase the dividend rate. Younger companies are often considered immature in running its business and they obtain lower profit, which then reduces the dividend rate. The categorization of companies based on company age has a positive effect on the dividend rate. Older companies are more mature and experienced in running their businesses, generate higher profits and are capable in minimizing the risk of loss (Muchtar, Hartono, \& Sari, 2020; Singla \& Samanta, 2018)

Previous studies have been carried out related to the factors affecting dividend policy, namely the previous year's dividend, agency cost, firm risk, profitability, company size, financial leverage, liquidity, company growth, growth opportunity, and company age as described in the following table.

Table 1. Results of previous studies: factors affecting the dividend policy

\begin{tabular}{|c|c|c|}
\hline \multirow{2}{*}{ Factors } & \multicolumn{2}{|c|}{ Results of previous studies } \\
\hline & Positive influence & Negative influence \\
\hline $\begin{array}{l}\text { Previous Year's } \\
\text { Dividen }\end{array}$ & $\begin{array}{l}\text { Alzomaia \& Al-Khadhiri (2013); Maldajian \& El } \\
\text { Khoury (2014); Meilita \& Rokhmawati (2017); } \\
\text { Ramli \& Arfan (2011); Sari (2017) }\end{array}$ & --------- \\
\hline Agency Cost & $\begin{array}{l}\text { Arfan \& Maywindlan (2013); Auditta et al. (2014); } \\
\text { Ramli \& Arfan (2011) }\end{array}$ & $\begin{array}{l}\text { Mardasari (2014); Parsian \& } \\
\text { Koloukhi (2014) }\end{array}$ \\
\hline Firm Risk & $\begin{array}{l}\text { Delikartika \& Ferry (2017); Maldajian \& El Khoury, } \\
\text { (2014) }\end{array}$ & Patra et al. (2012) \\
\hline Profitability & $\begin{array}{l}\text { Al-Ajmi \& Hussain (2011); Alzomaia \& Al- } \\
\text { Khadhiri (2013); Delikartika \& Ferry (2017); } \\
\text { Diantini \& Badjra (2016); Nurhayati (2013); } \\
\text { Oktaviani \& Basana (2015); Patra et al. (2012); } \\
\text { Ramli \& Arfan (2011); Rehman (2012); Singla \& } \\
\text { Samanta (2018); Yusof \& Ismail (2016) }\end{array}$ & -- \\
\hline Company Size & $\begin{array}{l}\text { Alzomaia \& Al-Khadhiri (2013); Maldajian \& El } \\
\text { Khoury (2014); Patra et al. (2012); Ranajee et al. } \\
\text { (2018); Sari (2017); Singla \& Samanta (2018); } \\
\text { Yusof \& Ismail (2016) }\end{array}$ & Pribadi \& Sampurno (2012) \\
\hline Financial Leverage & Parsian \& Koloukhi (2014) & $\begin{array}{l}\text { Oktaviani \& Basana (2015); } \\
\text { Patra et al. (2012); Pratiwi et al } \\
\text { (2016);.Sari \& Yusra (2018); } \\
\text { Yusof \& Ismail (2016) }\end{array}$ \\
\hline
\end{tabular}




\begin{tabular}{lll}
\hline Liquidity & $\begin{array}{l}\text { Diantini \& Badjra (2016); Patra et al. (2012); Sari \& } \\
\text { Sudjarni (2015) }\end{array}$ & $\begin{array}{l}\text { Nurhayati (2013) } \\
\text { Company Growth }\end{array}$ \\
& & $\begin{array}{l}\text { Sari \& Sudjarni (2015) } \\
\text { Maldajian \& El Khoury }\end{array}$ \\
Growth opportunity & Yusof \& Ismail (2016) & $\begin{array}{l}\text { (2014); Patra et al. (2012); } \\
\text { Rizqia et al. (2013); Saleem \& }\end{array}$ \\
Company Age & Badu (2019); Ranajee et al. (2018) & Rehman (2011) \\
\hline
\end{tabular}

Regarding to the objectives of this study and the literature review, the conceptual framework of this current study was proposed as follows.

\begin{tabular}{crc}
\hline $\begin{array}{c}\text { Independent variables } \\
\text { Previous year's dividend }\end{array}$ & Dependent variables \\
\hline Agency Cost & \\
Firm Risk & & DIVIDEND POLICY \\
Profitability & measured by Dividend Payout \\
Company Size & Ratio \\
Financial Leverage & \\
Liquidity & \\
Company Growth & \\
Growth Opportunity & \\
Company Age &
\end{tabular}

Figure 1. Conceptual framework

Source: Sharma \& Bakshi (2019)

\subsection{Development of Hypothesis}

Previous year's dividend rate affects the determination of the current year's dividend rate (Sari, 2017). Current year's dividend rate will improve the determination of the dividend rate in order to reach the company's goals for the welfare of shareholders. Decreases in the current year's dividend from the previous year's shows company's failure in reaching the company goals in maximizing shareholders' welfare (Alzomaia \& Al-Khadhiri, 2013; Maldajian \& El Khoury, 2014). Regarding the results of previous studies as described, the hypotheses of this current study were formulated as follows.

H1: Previous Year's Dividend has a positive and significant influence on Dividend Policy.

The agency cost incurred by the company to minimize agency problems is taken form cash flow. Greater agency cost issued will reduce the level of profitability which then reduces the dividend rate (Mardasari, 2014; Parsian \& Koloukhi, 2014). Thus, the hypothesis of this study was formulated as follows

H2: Agency Cost has a negative and significant influence on Dividend Policy.

The risk of companies with high P/E ratio proxies indicates investor expectations for higher profit growth in the future and applies to the opposite condition. The increase in the dividend rate, which is set to reduce the risk of future cash flows for shareholders, will also increase the share price and P/E ratio. A High P/E ratio is associated with lower risk and higher dividend rates. If low $\mathrm{P} / \mathrm{E}$ is associated with high risk, then a low dividend rate is low (Delikartika \& Ferry, 2017; Sharma \& Bakshi, 2019). Based on the description of the research results above, the following hypothesis was formulated:

H3: Firm Risk has a significant influence on Dividend Policy. 
Greater company profitability will increase the dividend rate since the dividend rate on net income is bigger, and vice versa (Al-Ajmi \& Hussain, 2011; Singla \& Samanta, 2018). Based on the description above, the following hypothesis was formulated:

H4: Profitability has a positive and significant influence on Dividend Policy.

Bigger company size is believed to generate greater profits, which will make the dividend rate higher (Alzomaia \& Al-Khadhiri, 2013). In certain conditions, when a company has positive outlook about the ability to earn profits, the company sets smaller dividend rate to spare more retained earnings for further investment (Pribadi \& Sampurno, 2012). From the description above, the following hypothesis was formulated:

H5: Company Size has a significant influence on Dividend Policy.

Bigger ratio of liabilities to equity will increase the interest on debt. The greater the debt on equity, which then causes costs, the lower the net income which then reduces the dividend rate (Yusof \& Ismail, 2016). From the description of the research results above, the following hypothesis was formulated:

H6: Financial Leverage has a negative and significant influence on Dividend Policy.

The more liquid the company, the higher its dividend payout. However, extremely high liquidity will create an impression that the company is unable to utilize current assets for business activities, which possibly reduces company profitability. These conditions even reduce the dividend rate (Patra et al., 2012). From the description above, the following hypothesis was formulated:

H7: Liquidity has significant influence on Dividend Policy.

Higher company growth rate indicates better business outlook. This condition will result in smaller dividend rate ratio against net profit in order to increase the amount of retained earnings for future investments (Sari \& Sudjarni, 2015; Sharma \& Bakshi, 2019; Silaban \& Purnawati, 2016). Based on this description, the following hypothesis was formulated:

H8: Company Growth has a negative and significant influence on Dividend Policy.

Higher market price is a sign of positive sentiment in stock market. The increase in market price against book value indicates better opportunities for further investment. Therefore, the dividend rate will be set smaller than the amount of retained earnings for further investment based on the company's business outlook (Maldajian \& El Khoury, 2014). Based on the description above, the following hypothesis was formulated:

H9: Growth Opportunity has a negative and significant influence on Dividend Policy.

The older a company, the better the ability to generate higher profits due to better business experience. Older companies tend to set higher dividend rate as they are capable of making greater profits (Badu, 2019; Ranajee et al., 2018). Thus, the following hypothesis was formulated:

H10: Company Size has a positive and significant influence on Dividend Policy.

\section{Method}

Hypotheses of this study were tested to examine the direction and significance of the influence of independent variables on the dependent variable. This study regarded unbalanced panel data of real estate, property, and construction companies engaged in property sectors listed in the Indonesia Stock Exchange (IDX) for seven years from 2013 - 2019. Unbalanced panel data regression analysis was carried out in the form of the ordinary least square technique using SPSS version 22 and E-Views version 10. 
Table 2. Calculations of the relevant variables

\begin{tabular}{|c|c|c|c|}
\hline Variable & $\begin{array}{l}\text { Measurement } \\
\text { Dimension }\end{array}$ & Formulation & Reference \\
\hline Dividend Policy & $\begin{array}{l}\text { Dividend } \\
\text { Payout Ratio } \\
\text { (DPR) }\end{array}$ & $D P R=\frac{\text { Dividen per Share }}{\text { Net Income per Share }}$ & $\begin{array}{l}\text { Arfan \& } \\
\text { Maywindlan } \\
\text { (2013); Sharma } \\
\text { \& Bakshi } \\
(2019)\end{array}$ \\
\hline $\begin{array}{l}\text { Previous Year' } \\
\text { Dividend (PYD) }\end{array}$ & $\begin{array}{l}\text { Previous } \\
\text { Year } \\
\text { Dividend } \\
\text { (PYD) }\end{array}$ & $P Y D=$ the previous year's dividend & $\begin{array}{l}\text { Sharma \& } \\
\text { Bakshi (2019) }\end{array}$ \\
\hline $\begin{array}{l}\text { Agency Cost } \\
\text { (AC) }\end{array}$ & $\begin{array}{l}\text { Free Cash } \\
\text { Flow }\end{array}$ & $F C F=\frac{\begin{array}{c}\text { Profit before Tax }+ \text { depreciation } \\
\text { +interest }- \text { capital expenditure }\end{array}}{\text { Total Assets }}$ & $\begin{array}{l}\text { Mardasari } \\
(2014) ; \text { Sharma } \\
\text { \& Bakshi } \\
(2019)\end{array}$ \\
\hline Firm Risk (FR) & $\begin{array}{l}\text { Price to } \\
\text { Earning Ratio }\end{array}$ & $P / E$ ratio $=\frac{\text { Market } \text { Price per Share }}{\text { Earning Per Share }}$ & $\begin{array}{l}\text { Sharma \& } \\
\text { Bakshi (2019) }\end{array}$ \\
\hline $\begin{array}{l}\text { Profitability } \\
\text { (PROF) }\end{array}$ & $\begin{array}{l}\text { Earning per } \\
\text { share }\end{array}$ & $E P S=\frac{\text { Earnings After Tax }}{\text { Outstanding Shares }}$ & $\begin{array}{l}\text { Sharma \& } \\
\text { Bakshi (2019); } \\
\text { Zutter \& Smart } \\
\text { (2019) }\end{array}$ \\
\hline $\begin{array}{l}\text { Company Size } \\
\text { (SIZE) }\end{array}$ & $\begin{array}{l}\text { Sales } \\
\text { Revenue }\end{array}$ & $S R=$ natural logaritm of sales revenue & $\begin{array}{l}\text { Sharma \& } \\
\text { Bakshi (2019) }\end{array}$ \\
\hline $\begin{array}{l}\text { Financial } \\
\text { Leverage (LEV) }\end{array}$ & $\begin{array}{l}\text { Debt to } \\
\text { Equity ratio }\end{array}$ & $D E R=\frac{\text { Total Liabilities }}{\text { Total Equity }}$ & $\begin{array}{l}\text { Sharma \& } \\
\text { Bakshi (2019); } \\
\text { Zutter \& Smart } \\
\text { 2019) }\end{array}$ \\
\hline Liquidity (LIQ) & Current ratio & $C R=\frac{\text { Current Assets }}{\text { Current Liabilities }}$ & $\begin{array}{l}\text { Hartono, } \\
\text { Lestari, } \\
\text { Wijaya, } \\
\text { Hartono, \& } \\
\text { Tinungki } \\
\text { (2020); Sharma } \\
\text { \& Bakshi } \\
(2019)\end{array}$ \\
\hline $\begin{array}{l}\text { Company } \\
\text { Growth } \\
\text { (GROWTH) }\end{array}$ & $\begin{array}{l}\text { Growth of } \\
\text { Assets }\end{array}$ & 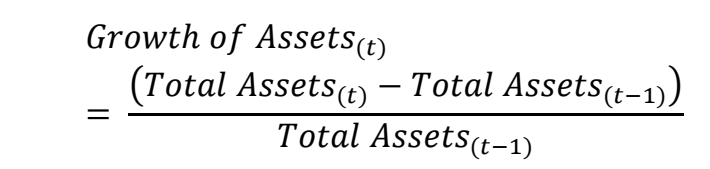 & $\begin{array}{l}\text { Sharma \& } \\
\text { Bakshi (2019) }\end{array}$ \\
\hline $\begin{array}{l}\text { Growth } \\
\text { Opporutunity } \\
\text { (GROPRT) }\end{array}$ & $\begin{array}{l}\text { Market Price } \\
\text { to Book } \\
\text { Value ratio }\end{array}$ & $P / B$ ratio $=\frac{\text { Market } \text { Price per Share }}{\text { Book Value per Share }}$ & $\begin{array}{l}\text { Sharma \& } \\
\text { Bakshi (2019) }\end{array}$ \\
\hline $\begin{array}{l}\text { Company Age } \\
\text { (AGE) }\end{array}$ & $\begin{array}{l}\text { Company } \\
\text { Age }\end{array}$ & $A G E=$ the square of logarithm of age & $\begin{array}{l}\text { Sharma \& } \\
\text { Bakshi (2019) }\end{array}$ \\
\hline
\end{tabular}

In this research, purposive sampling technique (Sekaran \& Bougie, 2016) was employed to select real estate, property, and building construction companies as samples. Companies that were in the process of delisting were excluded. Only companies that have paid out their dividends using the unbalanced panel data approach, and companies that have complete financial statements were included. Out of 91 companies listed on the IDX during the study period, 21 companies were initially selected as samples, with a total of 96 observed objects. 
The classical assumption test had to be conducted in unbalanced panel data regression using the ordinary least square approach. The classical assumption tests carried out in this study included the normality error test $(\varepsilon)$, multicollinearity test, autocorrelation test, and heteroscedasticity test. A total of 9 observation objects were considered outliers and were discarded in order to pass the classical assumption test, leaving 87 objects to be analyzed in the data processing (Lainun, Tinungki, \& Amran, 2018; Tinungki, 2019).

The normality test for errors was carried out using the Kolmogorov-Smirnov Test. The cut-off value for the normality error test was $\alpha>5 \%$, which result was in the form of violation-free normality assumption. The exact-sig.value was obtained at 0.969 , indicating thatexact-sig $>\alpha(5 \%)$. Therefore, the regression model in this study was declared violation-free in the normality assumption test.

Table 3. Variance inflation factor in the multicollinearity test

\begin{tabular}{lcccccccccc}
\hline Variable & PYD & AC & FR & PROF & SIZE & LEV & LIQ & GROWTH & GROPRT & AGE \\
\hline VIF & 2.005 & 1.255 & 1.936 & 1.709 & 1.847 & 1.707 & 1.412 & 1.620 & 2.482 & 1.398 \\
\hline
\end{tabular}

Source: Output of SPSS version 22.

The multicollinearity test was carried out with a variance inflation factor (VIF). The cut-off value for the multicollinearity test was set at VIF $<10$. The multicollinearity test resulted in VIF values for the previous year's dividend, agency cost, firm risk, profitability, company size, financial leverage, liquidity, company growth, growth opportunity, and company age $<10$. The results of this test indicated that the data were violation-free.

In the autocorrelation test using the Durbin Watson test, the cut-off value was set as recommended by Gujarati \& Porter (2011) at $\mathrm{dL}=1.4056$ and $\mathrm{dU}=1.9131$. Thus, areas between 1.9131 to $4-\mathrm{dU}=4$ $1.9131=2.0869$ are considered violation-free. The results of the durbin Watson test showed a value of 1,906 with margin which was categorized very small and was rounded down to the lower bound of the area free of autocorrelation assumptions. Hence, the regression model was declared free from violations of the autocorrelation assumption.

Heteroscedasticity test was carried out in the form of glacier test. The results of this test indicated that even when no outlier data was found, some variables remained to have sig values $<5 \%$, showing that the data were free from violations of the heteroscedasticity assumption.

The adjusted R2 was 59.3\%. Therefore, 59.3\% of the independent variables, namely the previous year's dividend, agency cost, firm risk, profitability, company size, financial leverage, liquidity, company growth, growth opportunity, and company age, can explain variations dividend policy by 59.3\%. Meanwhile, the rest $40.7 \%$ was explained by other independent variables outside this study.

The p-value obtained from the F-test on the regression model showed the influence of previous year's dividend, agency cost, firm risk, profitability, company size, financial leverage, liquidity, company growth, growth opportunity, and company age on dividend policy was 0.000 . Hence, there was at least 1 dependent variable with a significant effect on dividend policy as the dependent variable. 


\section{Results}

Table 4. Descriptive statistics

\begin{tabular}{lcrrrr}
\hline Proxied variable & $\mathrm{N}$ & \multicolumn{1}{c}{ Mean } & Mininum & Maximum & $\begin{array}{c}\text { Standard } \\
\text { deviation }\end{array}$ \\
\hline DPR & 87 & 0.15965 & 0.02382 & 0.63813 & 0.11890 \\
PYD & 87 & 130271.14 & 0.00000 & 1786226 & 216588.27 \\
FCF & 87 & 0.06086 & -0.36021 & 0.26856 & 0.07382 \\
PER & 87 & 13.64810 & 1.99369 & 50.77050 & 8.43042 \\
EPS & 87 & 228.33972 & 5.01432 & 1264.90333 & 363.61326 \\
SR & 87 & 14.40005 & 12.37695 & 16.27125 & 1.10538 \\
DER & 87 & 0.86825 & 0.08401 & 2.24187 & 0.44003 \\
CR & 87 & 2.50979 & 0.24050 & 11.39857 & 1.96397 \\
Growth & 87 & 0.17762 & -0.16422 & 1.48775 & 0.22152 \\
PBR & 87 & 1.75047 & 0.37713 & 7.60417 & 1.45733 \\
AGE & 87 & 2.25525 & 1.00000 & 2.79591 & 0.32155 \\
\hline SOurce & &
\end{tabular}

Source: Output of SPSS version 22.

The results of descriptive statistics are presented in table 3 including the mean values, minimum values, maximum values, and standard deviations for the 11 variables. A total of 87 samples of real estate, property, and construction property companies listed on the Indonesia Stock Exchange (BEI) were involved.

Table 5. The results of partial test

\begin{tabular}{lrrrr}
\hline $\begin{array}{l}\text { Proxied independent } \\
\text { variable }\end{array}$ & \multicolumn{3}{c}{$\begin{array}{c}\text { Dependent variable: dividend policy } \\
\text { Based on } \\
\text { Dividend payout ratio }\end{array}$} \\
\hline Constant & Coefficient & $\begin{array}{c}\text { Significance } \\
\text { (two-tailed) }\end{array}$ & $\begin{array}{c}\text { Significance } \\
\text { (one-tailed) }\end{array}$ & $\begin{array}{c}\text { Decision } \\
(\alpha=5 \%)\end{array}$ \\
PYD & 0.559 & 0.000 & 0.000 & ----- \\
FCF & 0.0000003134 & 0.000 & $* 0.000$ & Accepted \\
PER & -0.187 & 0.136 & $* 0.068$ & Rejected \\
EPS & -0.001 & $* 0.428$ & 0.214 & Rejected \\
ln SR & -0.00013 & 0.000 & $* 0.000$ & Rejected \\
DER & -0.040 & $* 0.000$ & 0.000 & Accepted \\
CR & 0.011 & 0.663 & $* 0.331$ & Rejected \\
GROWTH & 0.002 & $* 0.752$ & 0.376 & Rejected \\
PBR & -0.033 & 0.481 & $* 0.240$ & Rejected \\
Log ${ }^{2}$ AGE & 0.052 & 0.000 & $* 0.000$ & Rejected \\
\hline
\end{tabular}

Source: Output of SPSS version 22.

The results of descriptive statistics are presented in table 3 including the mean values, minimum values, maximum values, and standard deviations for the 11 variables. A total of 87 samples of real estate, property, and construction property companies listed on the Indonesia Stock Exchange (BEI) were involved. 


$$
\begin{gathered}
D P R=0,559+0,0000003134 P Y D-0,187 A C-0,001 P E R-0,00013 E P S-0,040 \ln S R \\
+0,011+0,002-0,033 G R O W T H+0,052 P B R-0,042 \log ^{2} A G E
\end{gathered}
$$

The results of descriptive statistics are presented in table 4 including the mean values, minimum values, maximum values, and standard deviations for the 11 variables. A total of 87 samples of real estate, property, and construction property companies listed on the Indonesia Stock Exchange (BEI) were involved.

\section{Discussion}

\section{H1: Previous Year's Dividend has a positive influence on Dividend Policy}

The results of regression test showed that previous year's dividend had an influence coefficient of 0.0000003134 with a significance value of 0.000 . Thus, previous year's dividend significantly and positively affected the dividend policy. These results support Sharma \& Bakshi (2019) who found that previous year's dividend has a positive and significant effect on dividend policy. The results of research conducted by Alzomaia \& Al-Khadhiri (2013); Meilita \& Rokhmawati (2017); Ramli \& Arfan (2011); and Sari (2017) also found similar results. It is evident that previous year's dividend rate is a benchmark in determining the current year's dividend rate. Therefore, dividend rate should not be set significantly lower than the previous year's (Sari, 2017; Sharma \& Bakshi, 2019). The company determines a higher current dividend rate, which refers to the previous dividend rate (Alzomaia \& Al-Khadhiri, 2013). Dividend signaling theory also supports that the current dividend distribution is a signal of dividend distribution in the future (Meilita \& Rokhmawati, 2017).

\section{H2: Agency Cost has a negative and significant influence on Dividend Policy}

The regression test showed that free cash flow had an influence coefficient of -0.187 with a significance value of 0.068 , indicating that agency cost had no influence on dividend policy. Likewise, Sharma \& Bakshi (2019) also stated that agency cost does not affect dividend policy. Similar results were also found by Bahri (2017); Pujiastuti (2008); and Yusof \& Ismail (2016). Agency cost issued to minimize agency conflict does not affect dividend policy Sharma \& Bakshi (2019). This insignificant negative effect is expected to illustrate that if the proportion of cash flow to total assets is higher, the company will pay dividends to be smaller (Pujiastuti, 2008). Free cash flow does not affect because the company allocates quite a lot of funds for capital expenditures so that it is not proven to be able to accommodate agency conflicts that occur in the company (Bahri, 2017).

\section{H3: Firm Risk has a significant influence on Dividend Policy}

Price to earnings ratio obtained an influence coefficient of -0.001 with a significance value of 0.428 , showing that firm risk did not affect dividend policy. On the contrary, Sharma \& Bakshi (2019) argued that firm risk has a positive influence on dividend policy. Meanwhile, Kaźmierska-Jóźwiak (2015) assured that firm risk does not affect dividend policy since stock market prices or market price fluctuation does not affect the dividend rate set by the company. Sari (2017) also found that the risk outcome does not affect dividend policy. It does not affect the risk of dividend policy because the large or small value of the price earnings ratio does not increase or decrease investors' risk in investing. Investors consider that the higher the value of the price to earnings ratio will increase risk and increase returns, but this shows the assumption of investors that the company will generate large returns to investors in the form of dividends due to higher risk is not proven (Delikartika \& Ferry, 2017)..

H4: Profitability has a positive and significant influence on Dividend Policy

The coefficient of earning per share was found at -0.00013 with a significance value of 0.000 . Therefore, profitability has no influence on dividend policy. Similarly, Sharma \& Bakshi (2019) stated 
that there is no influence of profitability on dividend policy. These results are also in line with Rizqia et al. (2013); and Sari (2017) who stated that profitability does not affect dividend policy. Hence, the level of net profit earned by a company is not proven to affect the determination of the dividend rate, where higher net profit leads to lower dividend rate as company management rather focuses on increasing the amount of retained earnings for future investment. A higher level of retained earnings indicates that companies prioritize their funding needs from internal financing through retained earnings (Rizqia et al., 2013).

\section{H5: Company Size has a significant influence on Dividend Policy}

The transformation of the natural logarithm of sales revenue has an influence coefficient of -0.040 with a significance value of 0.000 , showing that company size negatively affected on dividend policy. This result is contradictory to Sharma \& Bakshi (2019) who found that company size did not affect dividend policy. Several studies showed similar results as this current study including Nurhayati (2013); and Pribadi \& Sampurno (2012) who found that company size negatively affected dividend policy. It has been confirmed that companies with bigger company size and prospective business outlook tend to reduce the proportion of dividends and increase the amount of retained earnings for future investment (Pribadi \& Sampurno, 2012).

H6: Financial Leverage has a negative and significant influence on Dividend Policy

The regression test showed an influence coefficient of debt to equity ratio at 0.011 with a significance value of 0.331 . Therefore, financial leverage has no effect on dividend policy. This result supports Alzomaia \& Al-Khadhiri (2013); Delikartika \& Ferry (2017); Sharma \& Bakshi (2019); Singla \& Samanta (2018) in which financial leverage was found to have no influence on dividend policy. In another word, company's capital structure, which is a comparison between debt and equity has no effect on the determination of the dividend rate (Singla \& Samanta, 2018). In this condition, one of the common alternatives that the company makes is to prioritize the profit earned for debt repayment compared to dividend distribution. (Delikartika \& Ferry, 2017).

H7: Liquidity has a significant influence on Dividend Policy

In the regression test, the influence coefficient of current ration was 0.002 with a significance value of 0.376 , indicating that liquidity variable did not affect dividend policy. Similar result was also found by Sharma \& Bakshi (2019). Maldajian \& El Khoury (2014); Rehman (2012); and Singla \& Samanta (2018) also found similar results, stating that liquidity does not influence dividend policy. The absence of meaningful influence shows the level of liquidity of a company in relation to the ability to payout current liabilities in order to obtain greater profits has no influence on dividend policy (Singla \& Samanta, 2018). This condition shows that the company's current assets are prioritized for financing the company's short-term operations, further new investment, fulfilling short-term debt, or purchasing assets (Delikartika \& Ferry, 2017; Rehman, 2012).

H8: Company Growth has a negative and significant influence on Dividend Policy

The growth of total assets showed an influence coefficient of -0.033 with a significance value of 0.240 in the regression test. Hence, company growth variable did not affect the dividend policy. This result goes contradictory to Sharma \& Bakshi (2019) who found a negative influence between company growth and dividend policy. The results of this current study support the ones of Alzomaia \& AlKhadhiri (2013); Diantini \& Badjra (2016); and Pribadi \& Sampurno (2012) who confirmed that company growth does not affect dividend policy. In another word, the level of company growth does not affect the dividend rate set by a company. The growth of total assets is prioritized for allocating the company's business operations so that the company's assets are held at a high level and do not affect dividends. The higher the company's growth rate, the higher the need for funds to finance the company's 
total assets. The profit earned by the company is prioritized for financing the expansion or growth of the company rather than dividends (Diantini \& Badjra, 2016; Pribadi \& Sampurno, 2012).

\section{H9: Growth Opportunity has a negative and significant influence on Dividend Policy}

The regression test showed the market price to book value ratio obtained an influence coefficient of 0.052 with a significance value of 0.000 , showing that the growth opportunity had no influence on dividend policy. Sharma \& Bakshi (2019) also found similar results. In addition, this result also supports Pribadi \& Sampurno (2012) who did not find any influence of growth opportunity on dividend policy. Companies in a high growth rate condition require high company funds, then indirectly, they negatively affect the dividend rate. This high need is due to the company requiring funds earmarked to finance investment activities, expansion, and others. The company's internal funding originating from high retained earnings reduces the dividend portion of net income. However, this condition does not show a dominant significance because funds for expansion and investment are purely from the company's policies, which originate as a whole from retained earnings or debt (Pribadi \& Sampurno, 2012; Yusof \& Ismail, 2016).

H10: Company Age has a positive and significant influence on Dividend Policy

The regression test showed an influence coefficient of -0.042 with a significance value of 0.082 for the transformation of the squared logarithm of the company age. It indicates that company age had no effect on dividend policy. Similarly, Sharma \& Bakshi (2019) also did not find any influence of company age on dividend policy. Pratiwi et al. (2016); Sari (2017); and Singla \& Samanta (2018) also asserted that company growth does not affect dividend policy because the company age which is assumed to reflect company's maturity in running its business has no influence on dividend rate for shareholders. (Sari, 2017).

\section{Conclusions}

It can be drawn into conclusion that previous year's dividend has a positive influence on dividend policy, while company size has a negative influence on dividend policy. Whereas, agency cost, firm risk, profitability, financial leverage, liquidity, company growth, growth opportunity and company age have no significant influence on dividend policy.

Before increasing the dividend rate for shareholders, the real estate, property, and building construction companies should consider the previous year's dividend and company size by: (a) increasing the previous year's dividend rate to increase the current year's dividend rate; (b) maintaining firm size to be able to increase the dividend rate.

Prior to making investment in real estate, property, and building construction companies, investors are suggested to take into account company performance as reflected in the previous year's dividend and company size to ensure that their investment are profitable. This study also tries to test the conditions of the inconsistency of dividend distribution. Besides, this research fills the lacuna in the existing literature by focusing on analyzing by using the unbalanced panel data regression with the ordinary least square technique.

This study limitedly examined companies engaged in real estate, property, and building construction sector. Only 21 companies matched the criteria and were sampled. Future researchers are encouraged to develop this study by involving more samples from relevant sectors such as the infrastructure, utilities and transportation industries 


\section{Acknowledgements}

The first author gives thanks to Assoc. Prof. Georgina Maria Tinungki, Mr. Agus Budi Hartono, and Mrs. Maria Makapedua Tinungki for the contribution of thought in statistical data processing, construction of scientific thinking for research, and the partial funding support.

\section{References}

Agyei, S. K., \& Marfo-Yiadom, E. (2011). Dividend Policy and Bank Performance in Ghana. International Journal of Economics and Finance, 3(4), 202-207. https://doi.org/10.5539/ijef.v3n4p202

Al-Ajmi, J., \& Hussain, H. A. (2011). Corporate dividends decisions: evidence from Saudi Arabia. Journal of Risk Finance, 12(1), 41-56. https://doi.org/10.1108/15265941111100067

Alzomaia, T. S. F., \& Al-Khadhiri, A. (2013). Determination of Dividend Policy: The Evidence from Saudi Arabia. International Journal of Business and Social Science, 4(1), 181-192. Retrieved from www.ijbssnet.com

Arfan, M., \& Maywindlan, T. (2013). Pengaruh Arus Kas Bebas, Collateralizable Assets, Dan Kebijakan Utang Terhadap Kebijakan Dividen Pada Perusahaan Yang Terdaftar Di Jakarta Islamic Index. Jurnal Telaah Dan Riset Akuntansi, 6(2), 194-208.

Asif, A., Rasool, W., \& Kamal, Y. (2011). Impact of financial leverage on dividend policy: Empirical evidence from Karachi Stock Exchange-listed companies. African Journal of Business Management, 5(4), 1312-1324. https://doi.org/10.5897/AJBM10.838

Auditta, I. G., Sutrisno, \& Achsin, M. (2014). Pengaruh Agency Cost Terhadap Kebijakan. Jurnal Aplikasi Manajemen, 12(2), 284-294.

Badu, E. A. (2019). Determinants of Dividend Payout Policy of listed Financial Institutions in Ghana. Business, Management and Economics Research, 4(59), 134-141. https://doi.org/10.32861/bmer.59.134.141

Bahri, S. (2017). Faktor-Faktor Yang Mempengaruhi Kebijakan Dividen (Studi Pada Perusahaan Manufaktur yang Terdaftar di BEI). Jurnal Riset Akuntansi \& Komputerisasi Akuntansi, 8(1), 6384.

Black, F. (1976). The dividend puzzle. Journal of Portfolio Management, 5(8), 8-12. https://doi.org/10.3905/jpm.1996.008

Delikartika, L., \& Ferry. (2017). Faktor-Faktor Yang Mempengaruhi Kebijakan Dividen Perusahaan Non Keuangan Yang Terdaftar Di BEI. JRAK: Jurnal Riset Akuntansi Dan Komputerisasi Akuntansi, 19(4), 256-265. https://doi.org/10.33558/jrak.v8i1.882

Diantini, O., \& Badjra, I. (2016). Pengaruh Earning Per Share, Tingkat Pertumbuhan Perusahaan Dan Current Ratio Terhadap Kebijakan Dividen. E-Jurnal Manajemen Universitas Udayana, 5(11), 6795-6824.

Gujarati, D. N., \& Porter, D. C. (2011). Basic Econometrics (5th ed.). Boston, Mass: McGraw-Hill.

Hart, O., \& Zingales, L. (2017). Companies should maximize shareholder welfare not market value. Journal of Law, Finance, and Accounting, 2(2), 247-274. https://doi.org/10.1561/108.00000022 
Hartono, P. G., Lestari, H. S., Wijaya, R., Hartono, A. B., \& Tinungki, G. M. (2020). LIKUIDITAS SEBAGAI PREDIKTOR PROFITABILITAS: Sebuah Studi Empiris pada Perusahaan Sektor Industri Manufaktur. DERIVATIF: Jurnal Manajemen, 14(2).

Jensen, M. C., \& Meckling, W. H. (1976). THEORY OF THE FIRM: MANAGERIAL BEHAVIOR, AGENCY COSTS AND OWNERSHIP STRUCTURE. Journal of Financial Economics, 3, 305320.

Kaźmierska-Jóźwiak, B. (2015). Determinants of Dividend Policy: Evidence from Polish Listed Companies. Procedia Economics and Finance, 23(October 2014), 473-477. https://doi.org/10.1016/s2212-5671(15)00490-6

Kencana, M. R. B. (2019). Pertumbuhan Industri Properti yang Cepat Berdampak Besar ke Ekonomi. Www.Liputan6.Com, pp. 19-21. $\quad$ Retrieved from https://www.liputan6.com/bisnis/read/4065907/pertumbuhan-industri-properti-yang-cepatberdampak-besar-ke-ekonomi

Lainun, H., Tinungki, G. M., \& Amran, A. (2018). Perbandingan Penduga M, S, dan MM pada Regresi Linier dalam Menangani Keberadaan Outlier. Jurnal Matematika Statistika Dan Komputasi, 15(1), 88-96. https://doi.org/10.20956/jmsk.v15i1.4427

Leary, M. T., \& Michaely, R. (2011). Determinants of dividend smoothing: Empirical evidence. Review of Financial Studies, 24(10), 3197-3249. https://doi.org/10.1093/rfs/hhr072

Maldajian, C., \& El Khoury, R. (2014). Determinants of the Dividend Policy: An Empirical Study on the Lebanese Listed Banks. International Journal of Economics and Finance, 6(4), 240-256. https://doi.org/10.5539/ijef.v6n4p240

Mardasari, R. B. (2014). Pengaruh Insider Ownership, Kebijakan Hutang Dan Free Cash Flow Terhadap Nilai Perusahaan Melalui Kebijakan Dividen. Jurnal Ilmu Manajemen, 2(4), 1807-1820.

Masdupi, E. (2012). Pengaruh Insider Ownership, Struktur Modal, dan Pertumbuhan Perusahaan terhadap Kebijakan Deviden Perusahaan Syariah yang Terdaftar di Bursa Efek Indonesia. Economac, 12(1), 9-14.

Meilita, W., \& Rokhmawati, A. (2017). Pengaruh Kepemilikan Manajerial, Kepemilikan Institusional, Kepemilikan Asing, Kepemilikan Individu, Kebijakan Hutang dan Dividen Tahun Sebelumnya Berpengaruh Terhadap Kebijakan Dividen. Jurnal Tepak Manajemen Bisnis, IX(2), 215-232.

Muchtar, S., Hartono, P. G., \& Sari, W. R. (2020). The Effect of Corporate Governance on Sharia Corporate Performance in Indonesia. Advances in Economics, Business and Management Research, 151(International Conference on Management, Accounting, and Economy / ICMAE 2020), 192-196. https://doi.org/10.2991/iac-17.2018.49

Nurhayati, M. (2013). PROFITABILITAS, LIKUIDITAS DAN UKURAN PERUSAHAAN PENGARUHNYA TERHADAP KEBIJAKAN DIVIDEN DAN NILAI PERUSAHAAN SEKTOR NON JASA. Jurnal Keuangan Dan Bisnis, 5(2), 144-153.

Oktaviani, L., \& Basana, S. R. (2015). Analisa Faktor-Faktor yang Mempengaruhi Kebijakan Dividen (Studi Kasus Perusahaan Manufaktur 2009-2014). Journal of Research in Economics and Management, 15(02), 361-370. Retrieved from https://www.jrem.iseisby.or.id/index.php/id/article/download/28/26 
Parsian, H., \& Koloukhi, A. S. (2014). A study on the effect of free cash flow and profitability current ratio on dividend payout ratio: Evidence from Tehran Stock Exchange. Management Science Letters, 4, 63-70. https://doi.org/10.5267/j.msl.2013.11.033

Patra, T., Poshakwale, S., \& Ow-Yong, K. (2012). Determinants of corporate dividend policy in Greece. Applied Financial Economics, 22(13), 1079-1087. https://doi.org/10.1080/09603107.2011.639734

Pratiwi, R., Siswanto, E., \& Istanti, L. (2016). PengaruhReturn On Equity,Debt To Equity Ratiodan UmurPerusahaan Terhadap Kebijakan Dividen (Studi pada PerusahaanManufaktur yang Terdaftar di BEI Tahun 2014). Ekonomi Bisnis, 21(2), 136-145. https://doi.org/10.17977/um042v21i2p136145

Pribadi, A. S., \& Sampurno, R. D. (2012). Analisis Pengaruh Cash Position, Firm Size, Growth Opprtunity, Ownership, dan Return on asset terhadap Dividend Payout Ratio. Diponegoro Journal of Management, 1(4), 201-211. Retrieved from https://ejournal3.undip.ac.id/index.php/djom/article/view/800/774

Pujiastuti, T. (2008). Agency Cost Terhadap Kebijakan Dividen Pada Perusahaan Manufaktur Dan Jasa Yang Go Public Di Indonesia. Jurnal Keuangan Dan Perbankan, 12(2), 183-197.

Ramli, M. R., \& Arfan, M. (2011). Pengaruh Laba, Arus Kas Bebas Dan Pembayaran Dividen Kas Sebelumnya Terhadap Dividen Kas Yang Diterima Oleh Pemegang Saham (Studi Pada Perusahaan Manufaktur Terdaftar Di Bursa Efek Indonesia). Jurnal Telaah \& Riset Akuntansi, 4(2), earnings, operating cash flow, free cash flow, and. https://doi.org/10.17509/jaset.v4i2.10089

Ranajee, R., Pathak, R., \& Saxena, A. (2018). To pay or not to pay: what matters the most for dividend payments? International Journal of Managerial Finance, 14(2), 230-244. https://doi.org/10.1108/IJMF-07-2017-0144

Rehman, A. (2012). DETERMINANTS OF DIVIDEND PAYOUT RATIO: EVIDENCE FROM KARACHI STOCK EXCHANGE (KSE). Journal of Contemporary Issues in Business Research, 1(1), 20-27. https://doi.org/10.1177/1744987112460362

Rita, M. R., \& Sarquella, L. (2010). PENGARUH CORPORATE GOVERNANCE TERHADAP PERINGKAT OBLIGASI DAN YIELD OBLIGASI. Jurnal Manajemen Dan Keuangan, 8(1), 5971.

Rizqia, D. A., Aisjah, S., \& Sumiati. (2013). Effect of Managerial Ownership , Financial Leverage , Profitability, Firm Size, and Investment Opportunity on Dividend Policy and Firm Value. Research Journal of Finance and Accounting, 4(11), 120-130.

Saleem, Q., \& Rehman, R. U. (2011). Impacts of liquidity ratios on profitability (Case of oil and gas companies of Pakistan). Interdisciplinary Journal of Research in Business, 1(7), 95-98.

Sari, K. N., \& Sudjarni, L. (2015). Pengaruh Likuiditas, Leverage, Pertumbuhan Perusahaan, Dan Profitabilitas Terhadap Kebijakan Dividen Pada Perusahaan Manufaktur Di Bei. E-Jurnal Manajemen Universitas Udayana, 4(10), 3346-3374.

Sari, N. N., \& Yusra, I. (2018). ANALISIS LIKUIDITAS, LEVERAGE DAN KEBIJAKAN DIVIDEN BERDASARKAN SIKLUS HIDUP PERUSAHAAN PADA SAHAM LQ45. INA-Rxiv, 1-16. https://doi.org/10.17605/OSF.IO/UGKF5

Sari, W. R. (2017). Dividend policy of Indonesian state-owned enterprises. Telaah Bisnis, 18(1), 33-44. 
Sari, W. R., \& Matusin, A. R. (2019). Net Income and CSR Disclosure as Predictors Shares Price and Return per Share. Jurnal Dinamika Manajemen, 10(1), 81-91. https://doi.org/10.15294/jdm.v10i1.18946

Sekaran, U., \& Bougie, R. (2016). Reserach Methods for Bussiness A Skill-Bulding Approach (7th ed.). London: John Wiley \& Sons.

Sharma, R. K., \& Bakshi, A. (2019). An evident prescience of determinants of dividend policy of Indian real estate companies: An empirical analysis using co-integration regression and generalised method of moments. Journal of Financial Management of Property and Construction, 24(3), 358384. https://doi.org/10.1108/JFMPC-02-2019-0012

Silaban, D., \& Purnawati, N. (2016). Pengaruh Profitabilitas, Struktur Kepemilikan, Pertumbuhan Perusahaan Dan Efektivitas Usaha Terhadap Kebijakan Dividen Pada Perusahaan Manufaktur. EJurnal Manajemen Universitas Udayana, 5(2), 1251-1281.

Singla, H. K., \& Samanta, P. K. (2018). Determinants of dividend payout of construction companies: a panel data analysis. Journal of Financial Management of Property and Construction, 24(1), 19 38. https://doi.org/10.1108/JFMPC-06-2018-0030

Tahir, M., \& Mushtaq, M. (2016). Determinants of Dividend Payout: Evidence from listed Oil and Gas Companies of Pakistan. The Journal of Asian Finance, Economics and Business, 3(4), 25-37. https://doi.org/10.13106/jafeb.2016.vol3.no4.25

Tinungki, G. M. (2019). Orthogonal iteration process of determining K value on estimator of Jackknife ridge regression parameter. Journal of Physics: Conference Series, 1341(9). https://doi.org/10.1088/1742-6596/1341/9/092001

Wahjudi, E. (2020). Factors affecting dividend policy in manufacturing companies in Indonesia Stock Exchange. Journal of Management Development, 39(1), 4-17. https://doi.org/10.1108/JMD-072018-0211

Wilburn, K., \& Wilburn, R. (2014). The double bottom line: Profit and social benefit. Business Horizons, 57(1), 11-20. https://doi.org/10.1016/j.bushor.2013.10.001

Yusof, Y., \& Ismail, S. (2016). Determinants of dividend policy of public listed companies in Malaysia. Review of International Business and Strategy, 26(1), 88-99. https://doi.org/10.1108/RIBS-022014-0030

Zutter, C. J., \& Smart, S. B. (2019). Principles of Managerial Finance (15th ed.). London: Pearson. 
Penentu Kebijakan Dividen pada Perusahaan Real Estate, Properti, dan Konstruksi Gedung yang Terdaftar di BEI dengan Pendekatan Data Panel Tidak Seimbang

\begin{abstract}
Abstrak
Penelitian ini melibatkan perusahaan yang bergerak di bidang real estate, properti, dan konstruksi bangunan yang terdaftar di BEI periode 2013 - 2019 sebagai populasi. Penelitian ini mengkaji 10 faktor yang diduga mempengaruhi kebijakan dividen. Sebanyak 21 perusahaan membagikan dividen minimal satu kali selama periode penelitian, kemudian dipilih 96 sampel, sedangkan 9 sampel dibuang sebagai outlier sehingga dipilih 87 sampel. Regresi data panel tidak seimbang digunakan dengan menggunakan SPSS versi 22 dan E-Views versi 10 untuk menganalisis data dan menguji hipotesis. Hasil penelitian menunjukkan bahwa dividen tahun sebelumnya berpengaruh positif terhadap kebijakan dividen, sedangkan ukuran perusahaan berpengaruh negatif terhadap kebijakan dividen. Penelitian ini membuktikan bahwa deviden tahun sebelumnya dan ukuran perusahaan merupakan variabel kunci yang menentukan kebijakan deviden perusahaan dan menjadi pertimbangan investasi utama bagi investor untuk mendapatkan imbal hasil yang optimal. Penelitian ini juga mencoba menguji kondisi inkonsistensi pembagian dividen.
\end{abstract}

Kata kunci: kebijakan dividen, Bursa Efek Indonesia, real estat, properti, konstruksi bangunan, data panel tidak seimbang 